Bangladesh J. Bot. 48(4): 1153-1162, 2019 (December)

\title{
MICROMORPHOLOGICAL AND ANATOMICAL INVESTIGATIONS ON CONRINGIA HEIST. EX FABR.
}

\author{
Selami Selvi*, Hatice Inci Aladi ${ }^{1}$ and Mehmet Yavuz Paksoy ${ }^{2}$ \\ Programme of Medicinal and Aromatic Plants, Altinoluk Vocational School, \\ Ballkesir University, 10870 Edremit-Balıkesir, Turkey
}

Keywords: Conringia, Brassicaceae, Anatomical, Micromorphological investigation

\begin{abstract}
The micromorphological and anatomical investigations on 6 taxa of Conringia Heist. ex Fabr. growing in Turkey were carried out. The anatomy of root, stem and leaves was examined in detail. In micromorphological studies stem and leaf surface of species was examined. Mesophyll type of lamina is dorsiventral (Conringia planisiliqua, C. persica, C. austriaca) and equifacial (C. clavata, C.grandiflora, $C$. orientalis). Stomata situated on both surfaces, are anisocytic and rarely anomocytic types. Crystals of calcium oxalate observed in only one species ( $C$. grandiflora) was found to have cubic type parenchyma cells of the stem and leaf. In micromorphological studies the surface of the stem and leaves were found to be glabrous. Epidermal surface of leaves was observed to be covered with waxy cuticular particles. Anticlinal walls of the adaxial cells are undulate and rarely straight and anticlinal walls of abaxial epidermis are undulate and rarely sinuate. Periclinal walls were found to be covered with upper waxy layer which was flat. A diagnostic key based on combined stem, leaf and leaf epidermal characteristics are presented. The leaf mesophyll structures, stem vascular bundles number, lignified or unlignified of sclerenchyma, epidermal surface and absence or presence of crystals were found to be important characters for the identification of Conringia species.
\end{abstract}

\section{Introduction}

The Brassicaceae is represented by 337 genera and about 3350 species all over the world. Turkey is represented as one of the largest families (4th largest family) of the country with 98 genera, 605 species and 676 taxa in total (Appel and Al-Shehbaz 2003, Güner et al. 2012). However, while the northern temperate zone and especially the Mediterranean basin show a more intense distribution in Central and Southwest Asia, there are fewer species in the tropics and the southern hemisphere (Appel and Al-Shehbaz 2003). Many species of the Brassicaceae are cultivated today, because the members of this family contains many economically valuable plants such as important ornamentals, industrial plants, edible oils, animal feed, spices and vegetables (Siralı et al. 2013, Selvi and Paksoy 2013). Organic anions with glucose and sulfur content, commonly known as glycosinolates, are commonly found in species of Brassicaceae (Van Etten and Tookey 1983). The mirosinase-glycosinolate system introduced by the myrosinase enzyme and glycosinolate; affected biological activity in plants, fungi and herbivorous insects. In addition, it has been determined that dietary glucosinolates are precursors to cancer-inhibiting isothiocyanates (Özkur et al. 2007). Despite all of these benefits of glycosinolates, it also has negative effects on humans and some animals. These substances increase the amount of iodine in the thyroid hormone, causing the thyroid glands to swell and grow. Mustard oil glycosides cause stomach and intestinal diseases in farm animals (Y1lmaz et al. 2006).

*Author for correspondence: <sselvi2000@ yahoo.com>. ${ }^{1}$ Balıkesir University Institute of Science, Balikesir, Turkey. ${ }^{2}$ Department of Enviromental Engineering, Faculty of Engineering, Tunceli University. Tunceli, Turkey. 
Conringia Heist. Ex Fabr. one genus of Brassicaceae family containing single annual taxon constitutes one of the least studied genus of the family. Conringia spreads in Central Europe, the Mediterranean basin and Central Asia (Hedge 1965). The members of this genus is annual, glabrous, glaucous herbs with ovate or elliptical, entire, clasping leaves and yellow or white flowers (Hedge 1965). The genus is represented 8 taxa in the world and 6 taxa in Turkey, namely C. grandiflora Boiss. \& Heldr., C. orientalis (L.) Dumort., C. planisiliqua Fisch. \& Mey, C. persica Boiss., C. austriaca (Jacq.) Sweet, Hort. and C. clavata (C. A. Mey.) Busch. Out of these 6 taxa one endemic species is C. grandiflora in Turkey, and endemism rate is $17 \%$ (Güner et al. 2012). C. clavata is not included in Flora of Turkey (Hedge 1965), because taxa of this species known as $C$. perfoliata at first volume of this book is a synonym of $C$. clavata (Al-Shehbaz et al. 2007).

So far the anatomical and micromorphological properties of Conringia genus have not been studied. Therefore, the purpose of this study was to investigate micromorphologial and the anatomical characters to contribute to the systematic of the Conringia genus.

\section{Materials And Methods}

Plant species collected from different localities in Turkey are presented Table 1. Some of them were turned into herbarium samples, labelled and kept under protection at Botany laboratory of Balıkesir University (BAUN) Altınoluk Vocational School.

Table 1. Specimens used for anatomical studies and localities of specimen collection.

\begin{tabular}{ll}
\hline Species & Localities \\
\hline C. grandiflora & $\begin{array}{l}\text { Turkey, C3 Antalya: Alanya, Hacımahmetli village, field side, 150-200 m, 21.03.2014 / } \\
\text { (MY 138). }\end{array}$ \\
C. orientalis & $\begin{array}{l}\text { Turkey, A4 Ankara: Polatl, Kavuncu bridge near, swamp places, } 850 \mathrm{~m}, 24.04 .2014 \text { / } \\
\text { (MY 139). }\end{array}$ \\
C. planisiliqua & $\begin{array}{l}\text { Turkey, B5 Kurşehir: İnanç village opposite, Üçkuyu back, rocky places, } 1450 \mathrm{~m}, \\
\text { 15.05.2013 / (MY 140). }\end{array}$ \\
C. persica & Turkey, B9 Van: between Van- Başkale, Çuh passage, steppe, $2500 \mathrm{~m}, 29.05 .2013$ / (MY \\
& 141). \\
C. austriaca & Turkey, C5 Adana: Kozan, Gürümze village upper sections, forest clearance, $1350 \mathrm{~m}$, \\
& 18.04.2014 / (MY 142). \\
C. clavata & $\begin{array}{l}\text { Turkey, B5 Kayseri: Bünyan, Koramaz mountain, field side, steppe, } 1450-1500 \mathrm{~m}, \\
\text { 16.05.2014 / (MY 143). }\end{array}$ \\
\hline
\end{tabular}

In micromorphological studies, the epidermal surfaces of the taxa were examined in light microscope (LM) and the table top JCM-5000 scanning electron microscope (SEM). In the LM examinations, cross-sections taken manually from the stem and leaves of specimens and superficial sections taken from the upper and lower of the leaves were prepared and examined on the Olympus BX53 and Nikon Eclipse E 200. In the SEM examinations, the parts taken from the stem and leaves were placed on alumina stabs with double-sided adhesive tape and then examined at a voltage of $10 \mathrm{kV}$ on a NeoScope JCM-5000. For anatomical studies, the root, stem and leaves of the samples were kept in 70\% alcohol. Cross-section from middle of leaves, from root and stem were removed and stained with phloroglucinol-HCl solution. Chlorophyll in the leaves was removed with chloral hydrate (Yakar-Tan 1982). In anatomical studies, literatures were consulted to interpret sections of the root, stem and leaves (Metcalfe and Chalk 1950, Metcalfe and Chalk 1971, Fahn 1990 and Dickison 2000). Stomata index and stomata index ratio (Meidner and 
Mansifield 1968) were calculated by counting the number of epidermis and stomata in $\mathrm{mm}^{2}$ sections taken from the upper and lower surfaces of the leaves.

\section{Results and Discussion}

In root cross-section, the outermost part contains 1 - 2 layered epidermis cubic, rectangular or oval in shape. Cortex parenchyma consists of oval or crushed shaped 3 - 9 layers of cells. The endodermis layer is indistinguishable. Phloem consists of cubic or oval shaped $4-14$ layered parenchymatic cells. Under of the phloem there is xylem tissue in the circular structure. Xylem is formed polygonal or round shaped trachea cells. Rays consist of 2 - 8 series and sclerenchymatic. Pith region contains lignified or unlignified sclerenchymatic cells (Fig. 1).

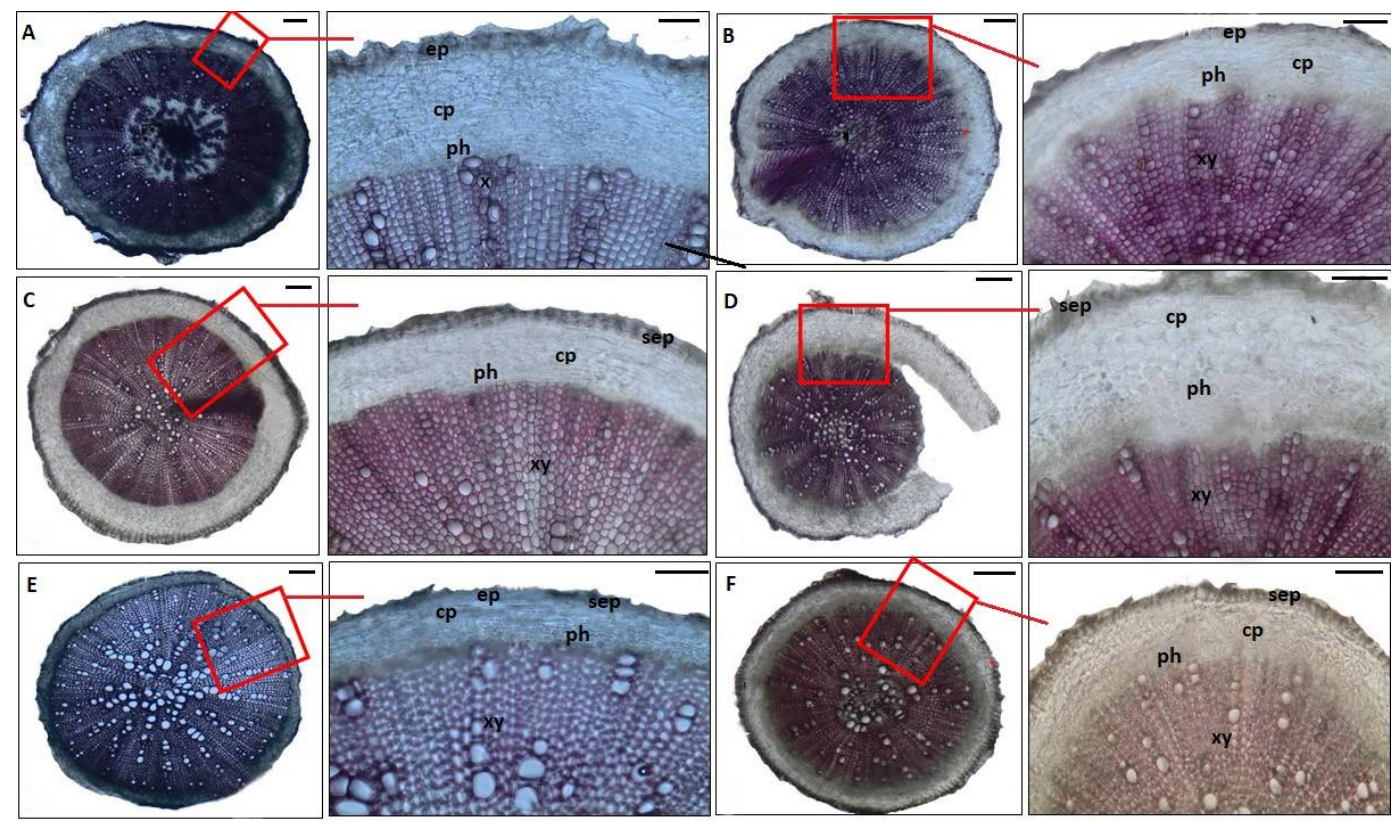

Fig. 1. Comparatively root cross-section of Conringia species. A. C. grandiflora, B. C. orientalis, C. C. planisiliqua, D. C. persica, E. C. austriaca, F. C. clavata. ep:epidermis, cp: cortex parenchyma, xy: xylem, ph: phloem (Scale: full section (left): $200 \mu \mathrm{m}$ and fragment section (right): $50 \mu \mathrm{m}$ ).

The xylem/root ratio ranged from 68.5 to $84.5 \%$. The area covered by xylem root was the highest in C. planisiliqua (84.5\%), while it was the least in C. austriaca (68.5\%). Root pith region of $C$. orientalis and C. planisiliqua, is formed from lignified cells; other species were observed in unlignified or weaky lignified (Fig. 6 C,D). Root anatomical characters of genus are presented Table 2.

In stem cross-section, the single-layered epidermis was found with a thin cuticle on the outside $(0.5-2.0 \mu \mathrm{m})$. The surface was glabrous. Amphistomatic type of stomata was present on the epidermis. Cortex layer consists of collenchyma (1 - 2 layers), cortex parenchyma (4 - 9 layers) and endodermis (1 - 2 layers). Pericycle is unclear. Vascular bundles (8 - 21) are arranged as a ring with sclerenchymatic cells. These bundles contain phloem sclerenchyma ( 1 - 3 layers), phloem (5 - 15 layers), cambium (unclearly) and xylem. Pith region occurred in the center of the stem composed of small or large orbicular and polygonal parenchymatic cells (Fig. 2). 
Table 2. Root anatomical characters of the species of genus Conringia.

\begin{tabular}{lcccccc}
\hline \multirow{2}{*}{ Species } & \multicolumn{5}{c}{ Root anatomic characters } \\
\cline { 2 - 6 } & Epidermis & $\begin{array}{c}\text { Cortex } \\
\text { layer }\end{array}$ & $\begin{array}{c}\text { Phloem } \\
\text { layer }\end{array}$ & $\begin{array}{c}\text { Ray } \\
\text { sequence }\end{array}$ & $\begin{array}{c}\text { Pith } \\
\text { region }\end{array}$ & $\begin{array}{c}\text { Xylem /root } \\
(\%)\end{array}$ \\
\hline C. grandiflora & $1-3$ & $7-9$ & $5-7$ & $2-4$ & Weaky or unlignified & 81 \\
C. orientalis & $1-2$ & $5-7$ & $5-7$ & $2-6$ & Lignified & 75,4 \\
C. planisiliqua & $1-2$ & $5-7$ & $5-7$ & $2-6$ & Lignified & 84,5 \\
C. persica & $1-3$ & $4-6$ & $4-6$ & $4-8$ & Weak lignified & 77,2 \\
C. austriaca & $1-2$ & $6-8$ & $10-14$ & $4-6$ & Weak lignified & 68,5 \\
C. clavata & $1-3$ & $3-5$ & $5-7$ & $2-6$ & Weak lignified & 79,8 \\
\hline
\end{tabular}
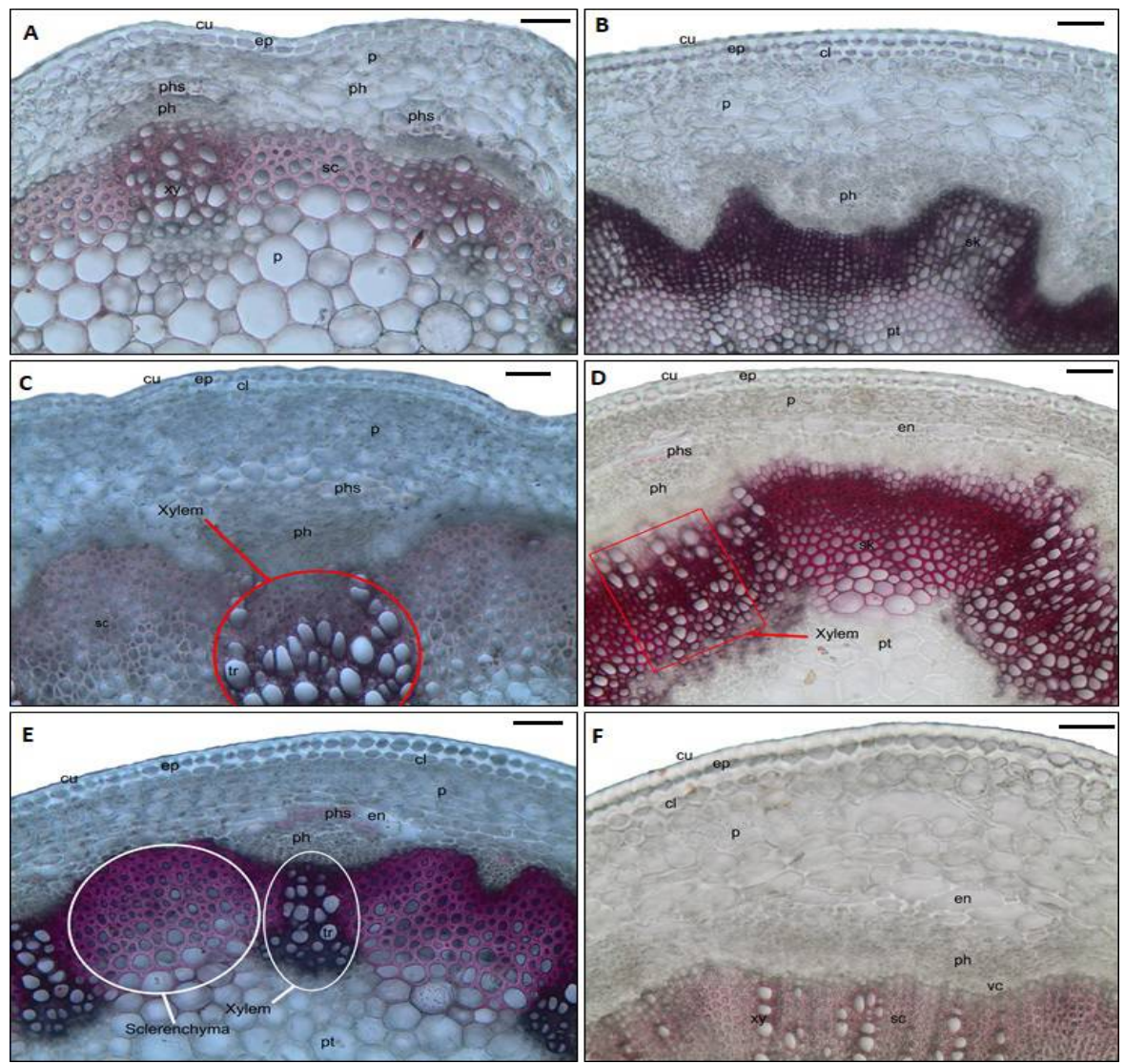

Fig. 2. Comparatively stem cross-section of Conringia species. A. C. grandiflora, B. C. orientalis, C. C. planisiliqua, D. C. persica, E. C. austriaca, F. C. clavata. cu: Cuticle, ep: Epidermal cell, cl: Collenchyma, p: Cortex parenchyma, en: Endodermis, xy: Xylem, ph: Phloem, phs: Phloem sclerenchyma, sc: Sclerenchyma and pt: Pith (scale $50 \mu \mathrm{m}$ ).

When the stem anatomical structures of the taxa are examined, it is seen that the most important characters separating from each other the taxa are vascular bundle number and phloem sclerenchyma (Table 3). Phloem sclerenchyma is not found in C. orientalis however, other species 
were found. Again, while C. orientalis and C. planisiliqua contain more than 20 vascular bundles, all other species contain less than 20 vascular bundles.

Table 3. Stem anatomical characters of the genus Conringia.

\begin{tabular}{lcccccc}
\hline & \multicolumn{5}{c}{ Stem anatomical characters } \\
\cline { 2 - 5 } Species & $\begin{array}{c}\text { Collenchyma } \\
\text { layer }\end{array}$ & $\begin{array}{c}\text { Cortex } \\
\text { layer }\end{array}$ & $\begin{array}{c}\text { Phloem } \\
\text { sclerenchyma }\end{array}$ & $\begin{array}{c}\text { Phloem } \\
\text { parenchyma }\end{array}$ & $\begin{array}{c}\text { Vascular } \\
\text { bundle } \\
\text { number }\end{array}$ & $\begin{array}{c}\text { Pith/Stem } \\
(\%)\end{array}$ \\
\hline C. grandiflora & - & $4-6$ & $2-3$ & $5-6$ & $6-9$ & 62 \\
C. orientalis & 1 & $6-8$ & - & $6-15$ & $23-27$ & 63 \\
C. planisiliqua & 1 & $7-9$ & $2-3$ & $8-10$ & $25-29$ & 67,6 \\
C. persica & - & $4-5$ & $1-2$ partially & $6-10$ & $6-10$ & 45 \\
C. austriaca & 1 & $6-8$ & $1-2$ & $8-10$ & $16-19$ & 61 \\
C. clavata & 1 & $6-8$ & $1-2$ partially & $8-10$ & $10-12$ & 48 \\
\hline
\end{tabular}

In the cross section of the leaf, there was a thin cuticle on the upper and lower epidermis. Both the epidermal cells were isodiametric and oval or cubic in shape. There was no trichomes on the surface of the epidermis. Mesophyll structure is variable. Dorsiventral type consisted of palisade parenchyma (2 - 3 layers) and spongy parenchyma (3 - 5 layers). Isobilateral (homogenous) type consisted of parenchymatic cells (Fig. 3).

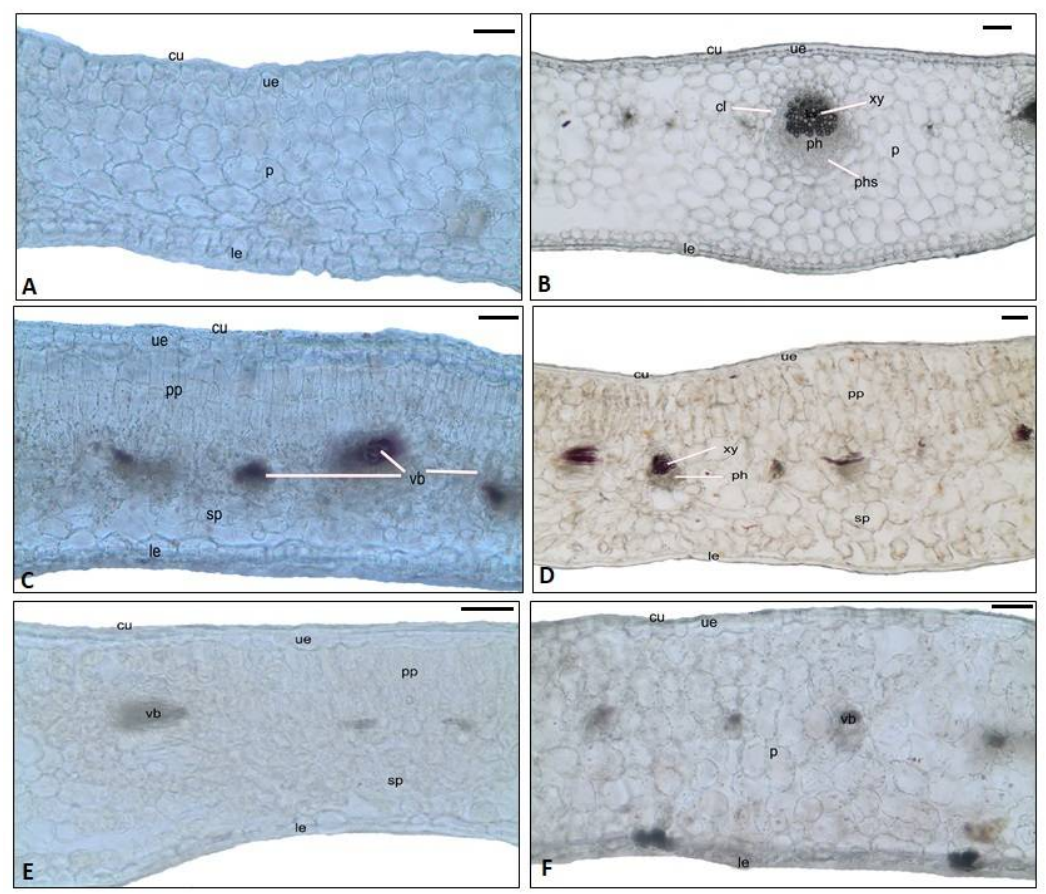

Fig. 3. Comparative lamina cross-section of Conringia species. A. C. grandiflora, B. C. orientalis, C. $C$. planisiliqua, D. C. persica, E. C. austriaca, F. C. clavata. cu: cuticle, ue: upper epidermis, p: parenchyma, pp: palisade parenchyma, sp: spongy parenchyma, xy: xylem, ph: phloem, phs: phloem sclerenchyma, le: lower epidermis and vb: vascular bundle (scale $50 \mu \mathrm{m}$ ). 
Stomata which were present on both surfaces of the leaf (amphistomatic type) were located on the same level as epidermal cells. The stomata were surrounded by three subsidiary cells of which one was usually more smaller than the other two, the Cruciferous (Anisocytic) type. In addition, anomocytic stomata type into some taxa was seen. Stomatal index was 19.9 - 31.3 (upper surface) and $24.4-32.5$ (lower surface), while stomatal index ratio was between 0.38 and 0.9 . In surface section, 3 different types of the epidermal cell walls were found which included large waves (sinuate), mild waves (undulate) or wave (straight). Vascular bundles of the larger veins nearly surrounded always by collenchyna. Bundles embedded in mesophyll were of collateral type. The xylem faces upper surface as against phloem in the lower epidermis. Sclerechyma on phloem tissue was absent. In the middle vein of lamina solitary or $2-3$ vascular bundles were situated (Fig. 4).

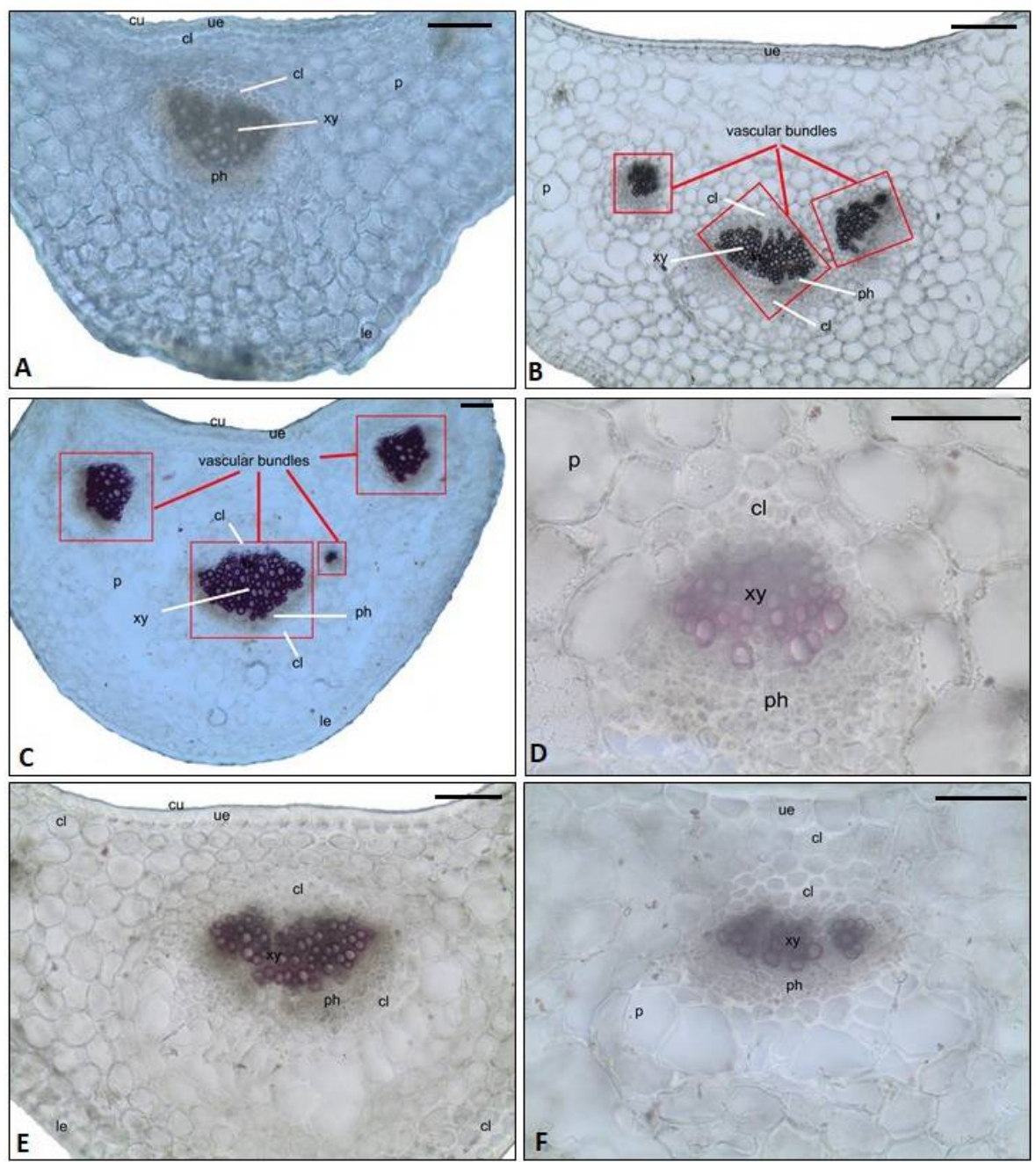

Fig. 4. Comparatively lamina middle vascular bundles of Conringia species. A. C. grandiflora, B. $C$. orientalis, C. C. planisiliqua, D. C. persica, E. C. austriaca, F. C. clavata. cu: cuticle, ue: upper epidermis, co: collenchyma, p: parenchyma, x: xylem, ph: phloem, psc: phloem sclerenchyma and le: lower epidermis (scale $50 \mu \mathrm{m}$ ). 
Cross-sections taken from the leaves showed differences in the mesophyll structures of the species and the number of vascular bundles in the middle vein regions. The mesophyll types observed in $C$. grandiflora, $C$. orientalis and $C$. clavata were isobilateral, while $C$. austriaca, $C$. planisiliqua and C. persica were dorsiventral (Table 4).

Table 4. Leaf anatomical characters of Conringia genus.

\begin{tabular}{|c|c|c|c|c|c|c|c|c|}
\hline \multirow{4}{*}{ Species } & \multicolumn{8}{|c|}{ Leaf anatomic characters } \\
\hline & \multirow{3}{*}{$\begin{array}{l}\text { Mesophyll } \\
\text { type }\end{array}$} & \multicolumn{3}{|c|}{ Mesophyll layer } & \multicolumn{4}{|c|}{ Middle vein area } \\
\hline & & \multirow[t]{2}{*}{$\begin{array}{c}\text { Palisade } \\
\text { layer }\end{array}$} & \multirow[t]{2}{*}{$\begin{array}{l}\text { Spongy } \\
\text { layer }\end{array}$} & \multirow[t]{2}{*}{ Parenchyma } & \multirow[t]{2}{*}{$\begin{array}{l}\text { Bundle } \\
\text { number }\end{array}$} & \multicolumn{2}{|c|}{$\begin{array}{c}\text { Parenchyma } \\
\text { layer }\end{array}$} & \multirow[t]{2}{*}{$\begin{array}{c}\text { Phloem } \\
\text { layer }\end{array}$} \\
\hline & & & & & & $\begin{array}{c}\text { Upper } \\
\text { epidermis }\end{array}$ & $\begin{array}{c}\text { Lower } \\
\text { epidermis }\end{array}$ & \\
\hline C. grandiflora & İsobilateral & - & - & $6-8$ & Single & $2-4$ & $5-7$ & $4-6$ \\
\hline C. orientalis & İsobilateral & - & - & $8-12$ & $2-4$ & $8-10$ & $5-7$ & $5-7$ \\
\hline C. planisiliqua & Dorsiventral & 2 & $3-5$ & - & $2-4$ & $6-7$ & $5-6$ & $6-7$ \\
\hline C. persica & Dorsiventral & $2-3$ & $3-5$ & - & Single & $1-3$ & $5-6$ & $5-6$ \\
\hline C. austriaca & Dorsiventral & 2 & $3-5$ & - & Single & $3-4$ & $8-10$ & $6-8$ \\
\hline C. clavata & İsobilateral & - & - & $8-10$ & Single & $1-2$ & $5-6$ & $6-8$ \\
\hline
\end{tabular}

In micromorphological studies there was no trichome on stems and leaves. The surface of the stems and leaves was sparsely and densely covered with particles waxy cuticular. Anticlinal walls of the upper and lower leaf epidermis cells undulate and straight; periclinal walls were covered with upper waxy layer and the flat. Epidermal surface of stem and lamina is shown in Fig. 5.

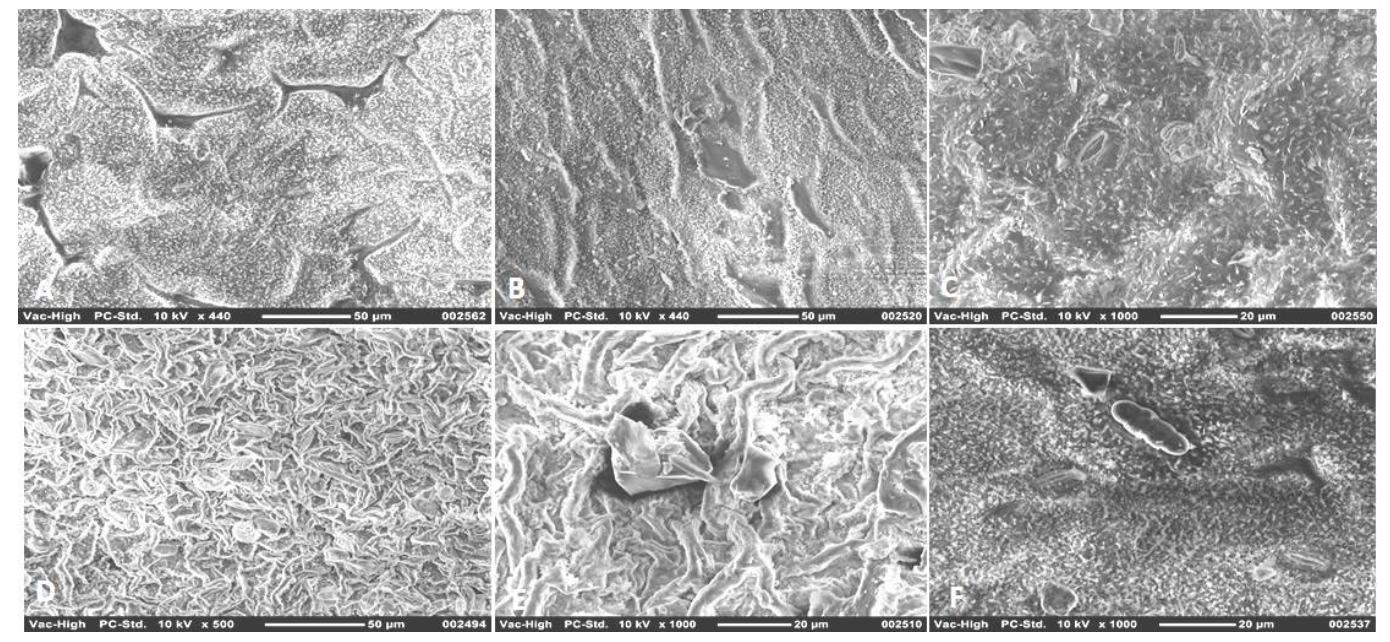

Fig. 5. Leaf epidermal surface (SEM). Adaxial surface: (C. planisiliqua (C), C. austriaca (E), C. clavata (F), Abaxial surface (C. grandiflora (A), C. orientalis (B), and C. persica (D) (scale $20 \mu \mathrm{m}$ ).

The number of the vascular bundle is divided into two as single or more than two. While C.orientalis and C. planisiliqua comprise more than two bundles, other species comprise single bundle (Fig. 4). In C. austriaca and $C$. planisiliqua, there was a row of collenchyma on the upper and lower epidermis of the middle leaf vein area. In $C$. orientalis and $C$. grandiflora, a row of collenchyma was observed on the lower epidermis in the $C$. clavata under the upper epidermis, 
whereas in $C$. persica collenchyma were not observed. The number of vascular bundles in the middle vein region varies between species (Fig. 4). It is also seen that, in all species in the middle vein region, the adaxial surface of the middle vein is curved inward (concave) and the abaxial

\section{Table 5. Characteristics of the leaf epidermis of Conringia species.}

\begin{tabular}{|c|c|c|c|c|c|c|c|c|c|c|c|c|}
\hline \multirow[t]{2}{*}{ Characters } & \multicolumn{2}{|c|}{ C. grandiflora } & \multicolumn{2}{|c|}{ C. orientalis } & \multicolumn{2}{|c|}{ C. planisiliqua } & \multicolumn{2}{|c|}{ C. persica } & \multicolumn{2}{|c|}{ C. austriaca } & \multicolumn{2}{|c|}{ C. clavata } \\
\hline & $\mathrm{Ad}^{*}$ & $\mathrm{Ab}^{*}$ & Ad. & $\mathrm{Ab}$. & Ad. & $\mathrm{Ab}$. & Ad. & $\mathrm{Ab}$. & Ad. & $\mathrm{Ab}$. & Ad. & $\mathrm{Ab}$. \\
\hline $\begin{array}{l}\text { Anticlinal cell } \\
\text { wall }\end{array}$ & $\begin{array}{l}\text { Und* } \\
\text { Str. }\end{array}$ & Und. & Str* & Und. & $\begin{array}{l}\text { Und. } \\
\text { Str }\end{array}$ & Und. & Und. & $\begin{array}{l}\text { Und. } \\
\text { Str. }\end{array}$ & Und. & Und. & Und. & $\begin{array}{l}\text { Und. } \\
\text { Str. }\end{array}$ \\
\hline Stomata type & $\mathrm{As}^{*}$ & As & As & As & $\begin{array}{c}\text { As } \\
\text { Anm* }\end{array}$ & As & As & $\begin{array}{c}\text { As } \\
\text { Anm. }\end{array}$ & $\begin{array}{c}\text { As } \\
\text { Anm. }\end{array}$ & As & As & As Anm. \\
\hline $\begin{array}{l}\text { Stomata length } \\
(\mu \mathrm{m})\end{array}$ & $18-22$ & $18-22$ & $14-19$ & $13-21$ & $18-22$ & $15-20$ & $18-27$ & $17-28$ & $16-21$ & $17-21$ & $24-29$ & $22-29$ \\
\hline $\begin{array}{l}\text { Stomata width } \\
(\mu \mathrm{m})\end{array}$ & $11-15$ & $13-18$ & $14-17$ & $11-16$ & $15-19$ & $15-18$ & $16-20$ & $15-20$ & $13-17$ & $16-18$ & $16-21$ & $16-22$ \\
\hline $\begin{array}{l}\text { Number of } \\
\text { stomata }\left(1 \mathrm{~mm}^{2}\right)\end{array}$ & 139 & 292 & 334 & 362 & 139 & 362 & 167 & 236 & 209 & 278 & 125 & 209 \\
\hline $\begin{array}{l}\text { Number of } \\
\text { epidermal cells }\end{array}$ & 557 & 905 & 752 & 1045 & 445 & 1003 & 404 & 557 & 599 & 696 & 376 & 431 \\
\hline Stomata index & 19.9 & 24.4 & 31.3 & 25.7 & 23.7 & 26.5 & 29.2 & 30 & 25.8 & 28.5 & 25.9 & 32.5 \\
\hline $\begin{array}{l}\text { Stomata index } \\
\text { ratio }\end{array}$ & \multicolumn{2}{|c|}{.5} & \multicolumn{2}{|c|}{0.9} & \multicolumn{2}{|c|}{0.38} & \multicolumn{2}{|c|}{0.7} & \multicolumn{2}{|c|}{0.75} & \multicolumn{2}{|r|}{0.6} \\
\hline
\end{tabular}

*Ad: Adaxial surface, Ab: Abaxial surface, Und. Undulate, Str. Straight, As.: Anisocytic, Anm: Anomocytic
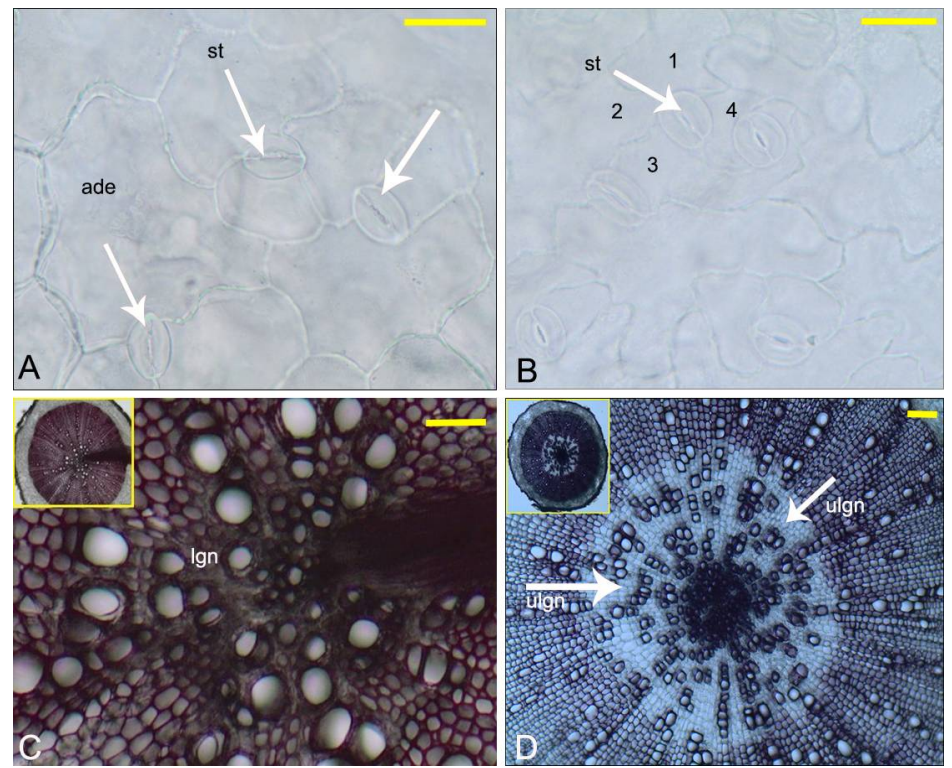

Fig. 6. Stomata types (A,B) and root pith region (C,D). A. Anisocytic type (C. planisiliqua; shown with arrows) B. Anomocytic type (C. clavata; surrounded with 4 cell (shown with arrow)). C. Root pith region of C. orientalis, D. Root pith region of $C$. grandiflora. ade: Adaxial epidermis, abe: Abaxial epidermis and st: Stomata (Scale: $50 \mu \mathrm{m}$ ). 
surface was convex (Fig. 4). Stoma type is a systematically important character (Metcalfe and Chalk 1950, Fahn 1990). When the leaf epidermal surface was examined, it was observed that the stomata were seen to be anisocytic ( 3 subsidiary cells of which 1 is usually much smaller than the other 2, the so-called cruciferous type) and anomocytic (surrounded by subsidiary cells four or more) (Table 5). Anisocytic type have been seen all of the taxa. But, anomocytic stoma type have been seen C. planisiliqua, D. C. persica, E. C. austriaca and C. clavata (Fig. 6 A,B).

Crystals are an important systematic character in anatomical studies (Metcalfe and Chalk 1950, Fahn 1990, Sargin and Selvi 2016). Crystals of calcium oxalate as cubic crystals, only one species ( $C$. grandiflora) was found to have cubic type parenchyma cells of the stem and leaf. As a result, the leaf mesophyll structures, stem vascular bundles number, lignified or unlignified of sclerenchyma, epidermal surface and absent or present of crystals were found to be important characters for the identification of Conringia species. Based on the anatomical features of the leaf, leaf surface and stem, a diagnostic key is presented below.

1. Leaf middle bundle single, stem vascular bundle number less than 20

2. Mesophyll type is dorsiventral

3. Stem vascular bundle number more than 10

C. austriaca

3. Stem vascular bundle number less than 10

C. persica

2. Mesophyll type is isobilaterale.

4. Stem phloem sclerenchyma nonlignified, vascular bundle 10-12, crystals absent

4. Stem phloem sclerenchyma lignified, vascular bundle less than 10 , crystals present

1. Leaf middle bundle two or three, stem vascular bundle number more than 20

5. Mesophyll type is isobilaterale, stem phloem sclerenchyma absent or unlignified.

5. Mesophyll type is dorsiventrale, stem phloem sclerenchyma present

\section{C. clavata}

C. grandiflora

\section{C. orientalis}

C. planisiliqua

\section{References}

Appel O and Al-Shehbaz IA 2003. Cruciferae. In: Kubitzki, K (ed) The families and genera of vascular plants. Vol 5 .

Al-Shehbaz İA, Mutlu, B and Dönmez AA (2007). The Brassicaceae (Cruciferae) of Turkey, updated. Turk J. Bot. 31: 327-336.

Dickison WC 2000. Integrative plant anatomy, Harcourt Academic, San Diego.

Fahn A 1990. Plant Anatomy, Fourty edition, Butterworth, Heinemann Pub. Ltd., Jarusalem, Israel.

Güner A, Aslan S, Ekim T, Vural M and Babaç MT 2012. Türkiye bitkileri listesi (Damarlı bitkiler). Nezahat Gökyiğit Botanik ve Flora Araştırmaları Derneği Yayını, İstanbul, 246-299.

Hedge IC 1965. Conringia Adans. In: Davis PH (eds.), Flora of Turkey and the East Aegean Island. vol 1: 275-279, Edinburgh University Press. Edinburgh.

Meidner H. and Mansifield TA 1968. Physiology of Stomata, Mc.Graw Hill., London, 67-68.

Metcalfe CR and Chalk L 1950. Anatomy of the Dicotyledons. Oxford Univ. Press, London, Vol. 2.

Metcalfe CR and Chalk L 1971. Anatomy of Monocotyledons. Oxford University Press, Oxford.

Özkur Ö, Bor M. and Özdemir F 2007. Bitkilerde mirosinaz glikosinolat sistemi. Anadolu Üniversitesi Bilim ve Teknoloji Dergisi, 8(2): 313-323.

Sargın SA and Selvi S 2016. Türkiye'de Yayılış Gösteren Cistus L. (Cistaceae) Cinsinin Karşılaştırmalı Yaprak Anatomisi, Iğdır Univ. J. Inst. Sci. \& Tech. 6(2): 41-48. 
Selvi S and Paksoy MY 2013. Comparative stem and leaf anatomy of the genus Ricotia L. (Cruciferae) growing in Turkey. Bangladesh Journal of Botany 42(1): 123-130.

Sıralı R, Uğur A, Zambi O, Dikmen A and Çağlar S 2013. Turpgiller (Brassicaceae) family asına ait bazı türlerin arıcılık açısından önemi. Akademik Ziraat Dergisi, 2(2): 107-115.

Van Etten, CH and Tookey HL 1983. Glucosinolates. In: Rechcigl M. (Ed.), Naturally Occurring Food Toxicants. CRC Press, Boca Raton, FL, 15-30.

Yakar-Tan N 1982. Bitki Mikroskopisi Klavuz Kitabı, İstanbul Üniversitesi, Fen Fakültesi, İstanbul. Yayın. No. 166.

Yılmaz H, Akpınar E and Yılmaz H 2006. Peyzaj mimarlığı çalışmalarında kullanılan bazı süs bitkilerinin toksikolojik özellikleri. Süleyman Demirel Üniversitesi, Orman Fakültesi Dergisi, A (1): 82-95.

(Manuscript received on 10 November, 2018; revised on 6 February, 2019) 